\title{
Rapid Transcriptional Activation and Early mRNA Turnover of Brain Natriuretic Peptide in Cardiocyte Hypertrophy

\author{
Evidence for Brain Natriuretic Peptide as an "Emergency" Cardiac Hormone against \\ Ventricular Overload
}

Osamu Nakagawa, Yoshihiro Ogawa, Hiroshi Itoh, Shin-ichi Suga, Yasato Komatsu, Ichiro Kishimoto, Kazuyoshi Nishino, Takaaki Yoshimasa, and Kazuwa Nakao

Second Division, Department of Medicine, Kyoto University Faculty of Medicine, Kyoto 606, Japan

\begin{abstract}
We previously demonstrated that brain natriuretic peptide (BNP) is a cardiac hormone mainly produced in the ventricle, while the major production site of atrial natriuretic peptide (ANP) is the atrium. To assess the pathophysiological role of BNP in ventricular overload, we have examined the gene expression of $\mathrm{BNP}$, in comparison with that of ANP, in a model of cardiac hypertrophy using cultured neonatal rat ventricular cardiocytes. During cardiocyte hypertrophy evoked by endothelin-1, phenylephrine, or PMA, the steady state level of BNP mRNA increased as rapidly as the "immediate-early" induction of the c-fos gene expression, and reached a maximal level within $1 \mathrm{~h}$. Actinomycin $D$, a transcriptional inhibitor, completely diminished the response, while the translational blockade with cycloheximide did not inhibit it. In contrast, ANP mRNA began to increase $3 \mathrm{~h}$ after the stimulation, and accumulated during cardiocyte hypertrophy. The BNP secretion from ventricular cardiocytes was also stimulated more rapidly than the ANP secretion. Furthermore, the turnover of BNP mRNA was significantly faster than that of ANP mRNA, being consistent with the existence of AUUUA motif in the 3 '-untranslated region of BNP $\mathrm{mRNA}$. These results demonstrate that the gene expression of BNP is distinctly regulated from that of ANP at transcriptional and posttranscriptional levels, and indicate that the characteristics of the BNP gene expression are suitable for its possible role as an "emergency" cardiac hormone against ventricular overload. (J. Clin. Invest. 1995. 96:1280-1287.) Key words: natriuretic peptides • ventricular cardiocytes • gene expression • messenger RNA • cardiac hypertrophy
\end{abstract}

Address correspondence to Kazuwa Nakao, MD, PhD, Second Division, Department of Medicine, Kyoto University Faculty of Medicine, 54 Shogoin Kawahara-cho, Sakyo-ku, Kyoto 606, Japan. Phone: 81-75751-3168; FAX:81-75-761-1195.

Received for publication 11 August 1993 and accepted in revised form 9 May 1995.

1. Abbreviations used in this paper: ANP, atrial natriuretic peptide; BNP, brain NP; ET-1, endothelin-1; HP-GPC, high performance gel permeation chromatography; -LI, like immunoreactivity; MLC-2, myosin light chain-2; PKC, protein kinase C.

J. Clin. Invest.

(c) The American Society for Clinical Investigation, Inc.

$0021-9738 / 95 / 09 / 1280 / 08 \quad \$ 2.00$

Volume 96, September 1995, 1280-1287

\section{Introduction}

The identification of atrial natriuretic peptide (ANP) ${ }^{1}$ in the cardiac atrium $(1,2)$ uncovered a new functional role of the heart as an endocrine organ regulating body fluid homeostasis and blood pressure control (3-5). ANP is mainly produced in and released from the atrium, and the plasma ANP concentration elevates in volume-overloaded states including congestive heart failure (6-8). In addition, the gene expression of ANP in the ventricle is markedly induced during the process of cardiac hypertrophy upon ventricular overload, and significantly contributes to the increase in the plasma ANP concentration in various cardiovascular disorders $(9-11)$.

Brain natriuretic peptide (BNP), originally isolated from the porcine brain (12), is a second member of natriuretic peptide family (3-5). We previously demonstrated that BNP is predominantly synthesized in and secreted from the cardiac ventricle (13-15). We have further shown that the ventricular gene expression of BNP is substantially augmented in response to ventricular overload in congestive heart failure, idiopathic cardiomyopathy, or hypertensive heart disease with cardiac hypertrophy (14-17). Although the plasma BNP concentration is approximately one-sixth of the plasma ANP concentration in healthy men, it markedly elevates in patients with congestive heart failure in parallel with its severity and surpasses the plasma ANP concentration in severe cases $(14,18-20)$. Furthermore, we have recently demonstrated that the plasma BNP concentration increases rapidly and tremendously, in contrast to the modest change of the plasma ANP concentration, in the early clinical course of acute myocardial infarction $(21,22)$. These findings indicate that the biosynthesis and secretion of BNP are distinctly regulated from those of ANP in response to ventricular overload, and suggest that BNP may have a discrete pathophysiological role in the maintenance of cardiovascular homeostasis.

The augmented productions of BNP and ANP in the hypertrophied myocardium can be considered as a compensation mechanism against ventricular overload, since BNP and ANP serve to reduce both cardiac preload and afterload by their natriuretic, diuretic, and vasodilatory actions (23-25). It will be of great importance to characterize the gene expressions of BNP and ANP during the development of cardiac hypertrophy, which also constitutes one of the principal adapting mechanisms against increased ventricular workload (26). The cellular mechanisms of the cardiac adaptations to ventricular overload, especially the expressions of various cardiac-specific genes, have been intensively examined using the cell culture models of cardiac hypertrophy, which closely reproduce the characteristics of in vivo hypertrophy (27-34).

To assess the pathophysiological significance of BNP in the 
compensation mechanism against cardiac overload, we examined the regulation of the BNP gene expression, in comparison with that of ANP, during the process of cardiocyte hypertrophy in cultured neonatal rat ventricular cardiocytes.

\section{Methods}

Cell culture. Apical halves of cardiac ventricles from 2- to 4-d-old Wistar rats were recovered and minced in a chilled balanced salt solution ( $116 \mathrm{mM} \mathrm{NaCl}, 20 \mathrm{mM}$ Hepes, $12.5 \mathrm{mM} \mathrm{NaH}_{2} \mathrm{PO}_{4}, 5.6 \mathrm{mM}$ glucose, $5.4 \mathrm{mM} \mathrm{KCl}, 0.8 \mathrm{mM} \mathrm{MgSO}_{4}$, pH 7.35) (28). Ventricular cardiocytes were dispersed in the balanced salt solution containing $0.04 \%$ collagenase II (Worthington Biochemical Corp., Freehold, NJ) and 0.06\% pancreatin (GIBCO Laboratories, Grand Island, NY) with agitation for 20 $\min$ at $37^{\circ} \mathrm{C}$. The digestion steps were repeated six times and the collected cell suspensions were mixed with $1 / 10$ vol of chilled FCS (Hazleton Biologics, Lenexa, KS) and pelleted by centrifugation. The pellets were combined in chilled FCS and kept at $4^{\circ} \mathrm{C}$.

The differentiation of myocytes from nonmyocytes was performed by the discontinuous Percoll gradient method (28). The discontinuous gradient of Percoll ( Sigma Chemical Co., St. Louis, MO) consisting of 40.5 and $58.5 \%$ was prepared in the balanced salt solution described above, and ventricular cells were suspended in the layer of $58.5 \%$ was prepared in the balanced salt solution described above, and ventricular cells were suspended in the layer of $58.5 \%$ Percoll. After centrifugation at $3,000 \mathrm{rpm}$ for $30 \mathrm{~min}$ at $15^{\circ} \mathrm{C}$, the cardiomyocytes selectively migrated to the interface of the discontinuous layers.

The purified myocytes were plated at a density of $3.6 \times 10^{4}$ cells/ $\mathrm{cm}^{2}\left(2.0 \times 10^{6}\right.$ cells $/ 10-\mathrm{cm}$ dish $)$ in the gelatin-coated culture dishes, in DME (Flow Laboratories, Irvine, United Kingdom) supplemented with $10 \% \mathrm{FCS}$ and antibiotics ( $100 \mathrm{U} / \mathrm{ml}$ penicillin $\mathrm{G}$ and $100 \mu \mathrm{g} / \mathrm{ml}$ streptomycin). Following 30-h incubation, the cells were maintained in serum-free DME for $10 \mathrm{~h}$. After the preconditioning period, the cultures were incubated in serum-free DME containing $1 \mathrm{mg} / \mathrm{ml}$ bovine serum albumin (Sigma Chemical Co.) with the following agents or vehicles: synthetic endothelin-1 (ET-1) (Peptide Institute, Osaka, Japan); phenylephrine, PMA, actinomycin D and cycloheximide (Sigma Chemical Co.); H-7 (Seikagaku Kogyo, Tokyo, Japan); calphostin C (a gift from Kyowa Hakko Kogyo, Tokyo, Japan).

High performance gel permeation chromatography (HP-GPC). The conditioned media were collected with $1 / 100 \mathrm{vol}$ of $1 \mathrm{mg} / \mathrm{ml}$ Triton $\mathrm{X}-100$, and acidified with $1 / 200$ vol of trifluoroacetic acid at $4^{\circ} \mathrm{C}$. Peptides were extracted from the medium samples using a Sep-Pak $\mathrm{C}_{18}$ cartridge (Millipore Corp., Milford, MA). HP-GPC was performed on a TSK-GEL G2,000 SW column $(7.5 \times 600 \mathrm{~mm}$ ) (Toyo Soda, Tokyo, Japan), eluted with $10 \mathrm{mM}$ trifluoroacetic acid containing $0.3 \mathrm{M} \mathrm{NaCl}$ and $30 \%$ acetonitrile as a solvent as previously reported $(14,35)$. An aliquot of each fraction was subjected to the RIAs for BNP and ANP without extraction.

RIAs for BNP and ANP. The BNP-like immunoreactivity (-LI) was determined by its specific RIA as previously reported (13). The minimal detectable quantity was $0.8 \mathrm{fmol} /$ tube. The cross-reactivities with $\alpha$-rat ANP and rat C-type natriuretic peptide, a third member of natriuretic peptide family $(3,4)$, in the RIA for rat BNP were $<0.1 \%$ on a molar basis. The ANP-LI was also measured by its specific RIA (9). The minimal detectable quantity was $0.3 \mathrm{fmol} /$ tube, and the cross-reactivities with rat BNP and rat C-type natriuretic peptide in the RIA for rat ANP were $<0.1 \%$ on a molar basis.

Probe preparations. The following probes were used for Northern blotting hybridizations: a 368-bp HincII-StuI fragment of rat ANP cDNA (9), a 468-bp fragment of rat BNP cDNA (16), a 484-bp human c-fos genomic probe (Takara Shuzo Co., Kyoto, Japan), and a 500bp fragment of rat myosin light chain-2 (MLC-2) cDNA prepared as follows.

The rat MLC- 2 cDNA probe was prepared by the cDNA synthesis and polymerase chain reaction (36), utilizing poly $(\mathrm{A})^{+} \mathrm{RNA}$ isolated from the rat heart. The synthetic primers were corresponding to the rat
MLC-2 cDNA sequence (37), with the addition of EcoRI and PstI cleavage sites at the 5'-ends: 5'-GAATTCTGCAGATGTCACCAAAGAAAGCCAAG-3' (sense) and 5'-GAATTCTGCAGTCAGTCCTTCTCTTCTCCGTG-3' (antisense). The sequence of the amplified product was confirmed to be identical to that of rat MLC-2 cDNA by the dideoxy chain termination method (36). The probe contains the entire coding sequence of rat MLC- 2 cDNA.

These probes were labeled by the random priming method (36) with $\left[\alpha-{ }^{32} \mathrm{P}\right] \mathrm{dCTP}$ (Amersham International, Little Chalfont, United Kingdom). Specific activity was $\sim 1 \times 10^{9} \mathrm{cpm} / \mu \mathrm{g}$ DNA.

Total RNA extraction and Northern blotting analyses. Total cellular RNA was extracted from cultured ventricular cardiocytes by the guanidinium thiocyanate $\mathrm{CsCl}$ method as previously reported (38). 2- $\mu \mathrm{g}$ aliquots of total cellular RNA were size-fractionated by electrophoresis on a $1.4 \%$ agarose-formaldehyde gel, and transferred to Biodyne A nylon membranes (Pall Corp. Glen Cove, NY). The membranes were prehybridized in $50 \mathrm{mM}$ sodium phosphate buffer ( $\mathrm{pH}$ 7.0) containing $50 \%$ formamide, $5 \times$ SSC, $5 \times$ Denhardt's solution (36), $0.1 \%$ SDS, and $250 \mu \mathrm{g} / \mathrm{ml}$ salmon sperm DNA at $42^{\circ} \mathrm{C}$ for $12-24 \mathrm{~h}$ and hybridized with ${ }^{32} \mathrm{P}$-labeled probes in the same solution mixture at $42^{\circ} \mathrm{C}$ for $20 \mathrm{~h}$. For the human c-fos genomic probe, prehybridization was performed at $65^{\circ} \mathrm{C}$ for $12 \mathrm{~h}$ in the solution containing $4 \times \mathrm{SSC}, 10 \times$ Denhardt's solution, $0.5 \%$ SDS, and $250 \mu \mathrm{g} / \mathrm{ml}$ salmon sperm DNA, followed by the hybridization at $42^{\circ} \mathrm{C}$ for $20 \mathrm{~h}$ in the solution composed of $50 \%$ formamide, $4 \times$ SSC, $5 \times$ Denhardt's solution, $0.5 \%$ SDS, $10 \%$ dextran sulfate, and $250 \mu \mathrm{g} / \mathrm{ml}$ salmon sperm DNA. The membranes were washed serially, with the final wash in $0.1 \times \mathrm{SSC}, 0.1 \% \mathrm{SDS}$ at $42^{\circ} \mathrm{C}$. The exposure time on autoradiography was $\sim 10 \mathrm{~h}$ (ANP), $16 \mathrm{~h}$ (BNP), $8 \mathrm{~h}$ (MLC-2), and $60 \mathrm{~h}$ (c-fos) with intensifying screens, respectively, and relative amount of each mRNA was determined by densitometric scanning in the linear response range of the $\mathrm{x}$-ray films.

Statistical analysis. Quantitative data were described as mean \pm SE, and statistical analyses were performed using Student's $t$ test.

\section{Results}

Secretions of BNP and ANP from cultured neonatal rat ventricular cardiocytes. The serial dilution curves of the conditioned media of cultured neonatal rat ventricular cardiocytes were parallel to the standard curves of rat BNP and $\alpha$-rat ANP in the RIAs for BNP and ANP, respectively (data not shown). Cultured ventricular cardiocytes in the control serum-free DME stably secreted BNP-LI as well as ANP-LI over $48 \mathrm{~h}$. The amounts of BNP-LI and ANP-LI in the control media after a $48-\mathrm{h}$ incubation were $2.81 \pm 0.257$ and $4.02 \pm 0.527 \mathrm{pmol} / \mathrm{dish}$, respectively (Fig. $1, A$ and $B$ ).

To further characterize the BNP and ANP secretions from cultured ventricular cardiocytes, the molecular forms of BNPLI and ANP-LI in the conditioned media were analyzed using HP-GPC coupled with RIAs (Fig. 2). BNP-LI in the control conditioned media consisted of two components with approximate molecular masses of 10 and $5 \mathrm{kD}$, in which the $5-\mathrm{kD}$ form was predominant (Fig. $2 \mathrm{~A}$ ). The elution position of 5-kD BNPLI was identical to that of synthetic rat BNP with 45 amino acids (39), which is a circulating form of rat BNP (40). The $10-\mathrm{kD}$ component corresponded to rat proBNP (13). As for ANP-LI, two components of 15 and $3 \mathrm{kD}$ emerged in the elution positions of $\gamma$-rat ANP (proANP) and synthetic $\alpha$-rat ANP (circulating form) (13), respectively (Fig. $2 A$ ). The two components of ANP-LI were almost equivalent in quantity.

Distinct stimulation of BNP and ANP secretions during ET1-induced cardiocyte hypertrophy. The treatment of cultured ventricular cardiocytes with ET-1 evoked apparent increase in cell size around $24 \mathrm{~h}$ after the stimulation (data not shown). The BNP-LI and ANP-LI secretions into culture media from 

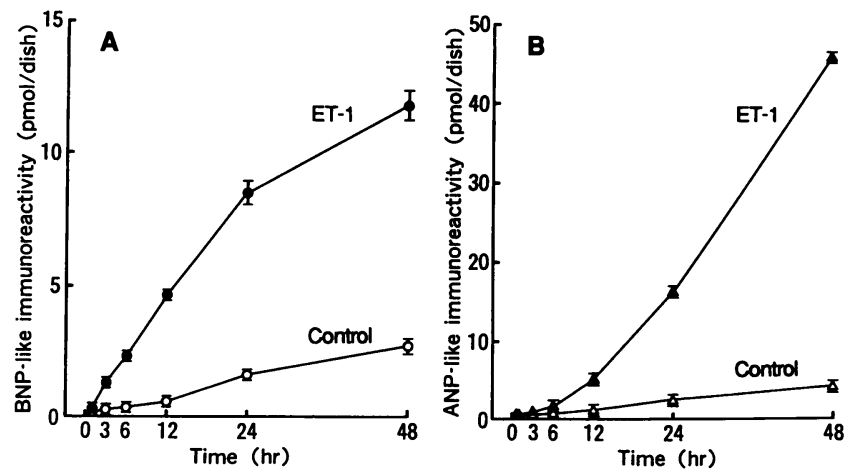

Figure 1. Distinct stimulation of BNP and ANP secretions by the treatment of ventricular cardiocytes with ET-1. Ventricular cardiocytes were incubated with $10^{-8} \mathrm{M}$ of ET-1 or vehicle. The medium samples were removed at indicated times and subjected to the RIAs for BNP and ANP. Results are presented as the mean value of triplicate assay samples for each time point, with error bars representing SE. $(A)$ BNP-LI, closed circles; ET-1, open circles; vehicle. $(B)$ ANP-LI, closed triangles; ET-1, open triangles; vehicle.

ventricular cardiocytes were stimulated in a dose-dependent fashion during ET-1-induced cell hypertrophy. Maximal response of BNP-LI release in the 48-h incubation was 3.7-fold vs. control, which was obtained with ET-1 concentrations of $10^{-10}-10^{-8} \mathrm{M}$. As for the ANP-LI release, maximal induction (10-fold vs. control) also occurred with $10^{-10}-10^{-8} \mathrm{M}$ of ET- 1 . The $50 \%$ effective concentration values were $\sim 3 \times 10^{-11}$ M. As shown in Fig. 2 B, BNP-LI and ANP-LI in the conditioned media of ET-1-treated hypertrophied ventricular cells exhibited essentially the same HP-GPC profiles as those in the control conditioned media.

We next examined the temporal profile of the BNP and ANP secretions during the course of ET-1-induced cardiocyte hypertrophy. The BNP-LI secretion was rapidly induced by the treatment with ET-1, and the fold increase vs. control reached its maximum within $3 \mathrm{~h}$ (Fig. $1 \mathrm{~A}$ ). Thereafter, the maximally increased BNP-LI release was maintained until $24 \mathrm{~h}$ after the treatment. In contrast, the stimulation of the ANP-LI release

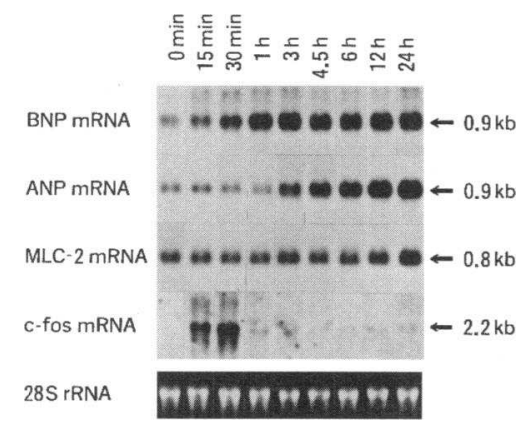

Figure 3. Differential gene expressions of BNP, ANP, MLC-2, and c-fos during ET-1evoked cardiocyte hypertrophy. After indicated times of incubation with ET-1 $\left(10^{-8} \mathrm{M}\right)$, the cells were harvested for the isolation of total RNA and the steady state levels of various mRNAs were assessed by Northern blotting analyses. The same membrane ( $2 \mu \mathrm{g}$ of total RNA/lane) was reused for the hybridizations.

was observed from several hours after the treatment and was time dependently augmented during myocardial cell hypertrophy (Fig. $1 B$ ).

Differential gene expressions of BNP and ANP during cardiocyte hypertrophy. To further investigate the differential activation of the BNP and ANP productions in cultured ventricular cardiocytes, we examined the temporal profiles of the BNP mRNA and ANP mRNA levels during ET-1 -evoked cardiocyte hypertrophy. The treatment of ventricular cardiocytes with ET1 evoked cardiocyte hypertrophy, which was characterized by well-known phenotypic and genetic features of cardiocyte hypertrophy $(28,29,31)$, as follows. As demonstrated in Fig. 3, the stimulation of ventricular cardiocytes with ET-1 $\left(10^{-8} \mathrm{M}\right)$ evoked rapid and transient increase in the c-fos mRNA level within $15 \mathrm{~min}$. The MLC-2 mRNA level gradually increased from $12 \mathrm{~h}$ after the stimulation, followed by increase in cell size observed obviously around $24 \mathrm{~h}$.

In this course of cardiocyte hypertrophy, the steady state level of BNP mRNA immediately increased within 15 min after the treatment with ET-1, reaching a maximal level at $1 \mathrm{~h}$ (386 $\pm 30.4 \%$ of control cells, $P<0.01, n=12$ ) (Figs. 3 and $4)$. On the other hand, ANP mRNA began to increase $3 \mathrm{~h}$ after the treatment with ET-1, and gradually accumulated during myocardial cell hypertrophy.
A

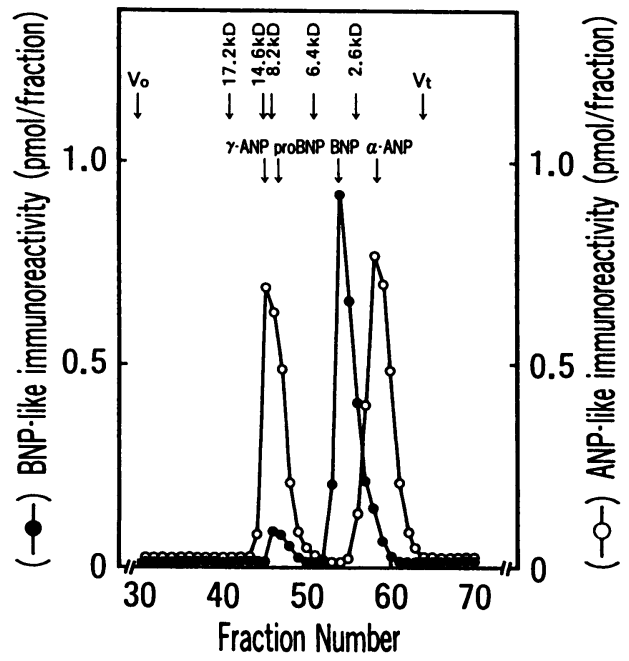

1282
B

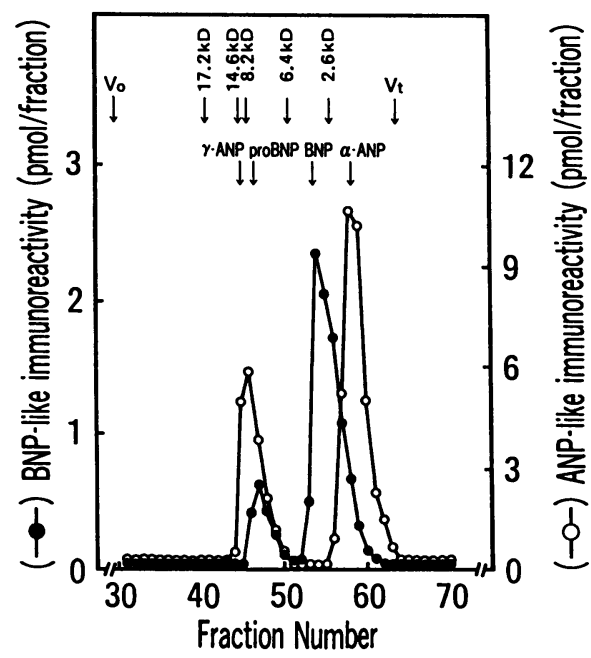

Figure 2. Molecular forms of BNP and ANP secreted from cultured ventricular cardiocytes. Ventricular cardiocytes were incubated with $10^{-8} \mathrm{M}$ of ET-1 or vehicle for 48 h. (A) Vehicle. (B) ET-1. Closed circles; BNP-LI, open circles; ANP-LI. Arrows denote elution positions of polypeptide molecular weight calibration kit (Pharmacia LKB Biotechnology AB, Uppsala, Sweden ), void volume $(V o)$, and total volume $(V t)$. Elution positions of synthetic rat BNP, synthetic $\alpha$-rat ANP, purified rat proBNP, and purified $\gamma$ rat ANP are also indicated. 
A

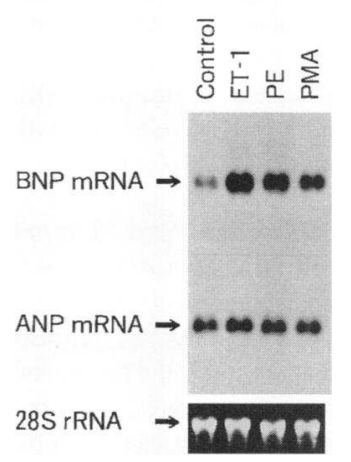

B

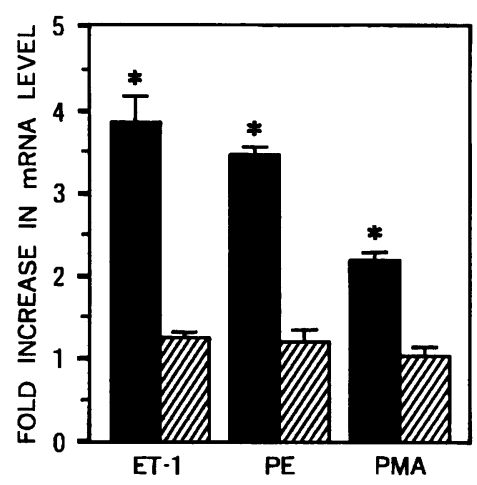

Figure 4. Rapid induction of BNP gene expression via protein kinase $\mathrm{C}$ activation. Ventricular cardiocytes were treated with ET-1 $\left(10^{-8} \mathrm{M}\right)$, phenylephrine $(P E)\left(10^{-4} \mathrm{M}\right)$, PMA $\left(10^{-6} \mathrm{M}\right)$ for $1 \mathrm{~h}$. Total RNA extraction and Northern blotting analyses on BNP mRNA and ANP mRNA were performed as described in Methods. Representative results are shown in Panel $A$, and the quantitative analyses by the densitometric scanning are shown in Panel $B$. The data are presented as fold-increases against control (mean values with SE). Filled bars; BNP mRNA, hatched bars; ANP mRNA, $* P<0.001$ compared with control.

Involvement of protein kinase $C(P K C)$ activation in rapid induction of BNP gene expression. We further analyzed the BNP gene expression in cardiocyte hypertrophy evoked by the treatment with agents other than ET-1. The treatment with phenylephrine $\left(10^{-4} \mathrm{M}\right)$ or PMA $\left(10^{-6} \mathrm{M}\right)$ induced cardiocyte hypertrophy with increase in cell size and augmented expression of the MLC-2 gene around $24 \mathrm{~h}$ (not shown). As was the case with ET-1, rapid increase in the steady state level of BNP mRNA was induced within $1 \mathrm{~h}$ by the treatment with phenylephrine $(348 \pm 8.55 \%$ vs. control, $P<0.01, n=3)$ or PMA $(218 \pm 8.73 \%, P<0.01, n=3$ ) (Fig. $4, A$ and $B$ ), while there were no significant changes in the ANP mRNA level at $1 \mathrm{~h}$. The mRNA level of ANP increased later during the establishment of cell hypertrophy, as observed by the treatment with ET-1 (data not shown).

Since ET-1, phenylephrine, and PMA were known to activate $\mathrm{PKC}$ in the intracellular signaling pathway, we examined the effects of PKC inhibitors (41) on the BNP gene expression. H-7 (a nonspecific PKC inhibitor) and calphostin C (a highly selective PKC inhibitor) both clearly suppressed the ET-1induced rapid increase in the BNP mRNA level at $1 \mathrm{~h}$ (Fig. 5 ). The BNP mRNA level in cardiocytes simultaneously treated with ET-1 and H-7, or ET-1 and calphostin C was 55.3 $\pm 4.13 \%$ $(P<0.01, n=4)$ and $49.7 \pm 7.75 \%(P<0.01, n=4)$, respectively, as compared with that of ET-1-treated cardiocytes. These findings suggest that the rapid induction of the BNP gene expression during cardiocyte hypertrophy is mediated via, at least in part, PKC activation.

Rapid transcriptional activation of BNP gene in protein synthesis-independent mechanism. As seen in Fig. 6, actinomycin $\mathrm{D}$, an inhibitor of gene transcription, completely diminished the ET-1-induced increase in the BNP mRNA level (ET-1 + AMD: $79.6 \pm 10.4 \%$ of control cells, $n=3$ ). On the other hand, the treatment with ET-1 could evoke rapid increase in the BNP mRNA level even in the presence of cycloheximide, a protein synthesis inhibitor (ET-1 + CHX: $91.2 \pm 3.90 \%$ of ET-1-treated cells, $n=3$ ). Thus, the rapid induction of the

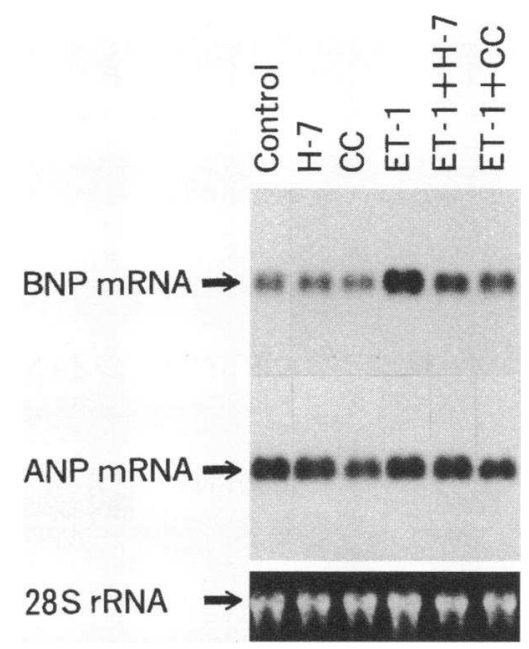

Figure 5. Inhibition of ET-1-induced rapid BNP gene expression by treatment with protein kinase $\mathrm{C}$ inhibitors. Ventricular myocytes were simultaneously treated with ET$1\left(10^{-8} \mathrm{M}\right)$ and $\mathrm{H}-7(10$ $\mu \mathrm{g} / \mathrm{ml})$, or ET-1 $\left(10^{-8}\right.$ $\mathrm{M})$ and calphostin $\mathrm{C}$ (CC) $\left(10^{-6} \mathrm{M}\right)$ for $1 \mathrm{~h}$, and their effects on ET1 -evoked BNP gene expression were evaluated by Northern blotting analyses.

BNP gene expression by the treatment with ET-1 occurs through the transcriptional up-regulation, and this induction does not require de novo synthesis of transacting regulatory proteins.

Rapid turnover of BNP MRNA in cultured ventricular cardiocytes. Fig. $7(A$ and $B$ ) shows the turnover of BNP mRNA and ANP mRNA in cultured ventricular cardiocytes. After the transcriptional inhibition by the treatment with actinomycin D, the steady state levels of BNP mRNA and ANP mRNA at the indicated times were measured to evaluate the disappearance rates of preexisting mRNAs.

We evaluated the turnover rates of BNP mRNA and ANP mRNA in ventricular cardiocytes in basal, serum-free condition (Fig. $7 \mathrm{~A}$ ). In addition, we examined the mRNA turnover in hypertrophied cells, which were incubated with $10^{-8} \mathrm{M}$ of ET1 for $36 \mathrm{~h}$ and were further treated with actinomycin D (Fig. $7 \mathrm{~B}$ ). In both states, BNP mRNA was rapidly degraded in ventricular cardiocytes, in contrast to ANP mRNA. In basal, serum-free condition, the BNP mRNA levels at 2,6 , and $12 \mathrm{~h}$ after the treatment were 67,38 , and $16 \%$ of control $(0 \mathrm{~h})$, respectively (mean of triplicated determinations, half life $=4$ h) (Fig. $7 \mathrm{~A}$ ). In hypertrophied condition, the BNP mRNA levels at 2,6 , and $12 \mathrm{~h}$ were 78,54 , and $31 \%$ of control $(0 \mathrm{~h})$, respectively (mean of triplicates, half life $=7 \mathrm{~h}$ ) $($ Fig. $7 \mathrm{~B})$.

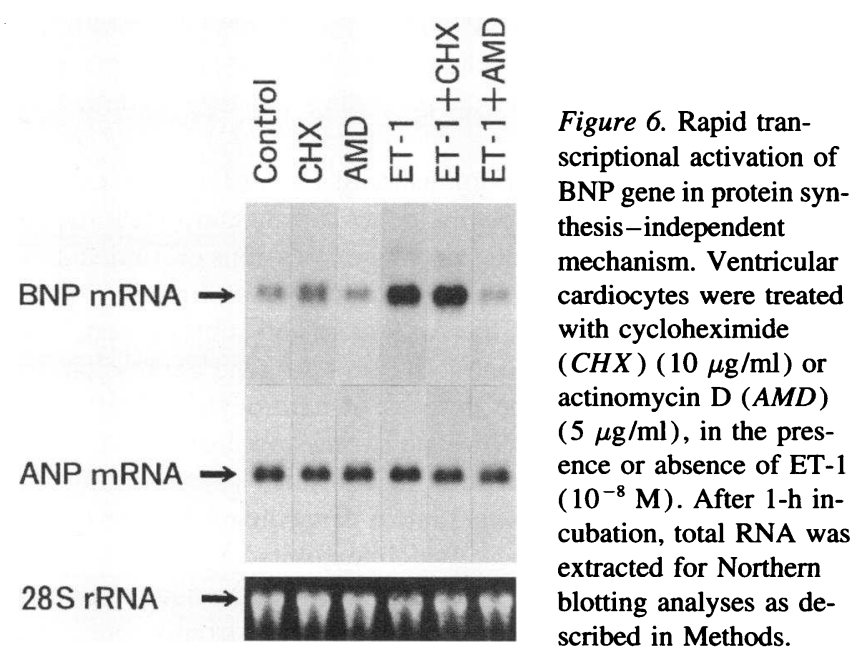


A

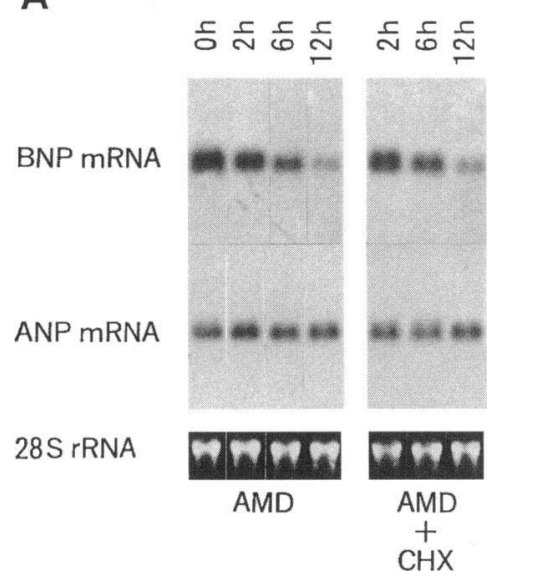

B

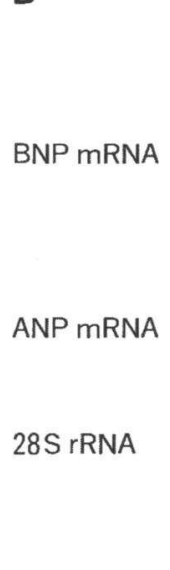

C

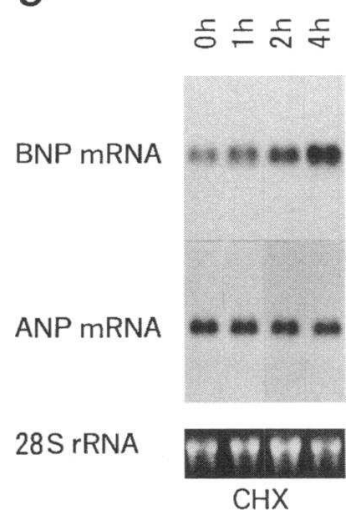

Figure 7. Rapid turnover of BNP mRNA through translation-dependent mechanism in cultured ventricular cardiocytes. $(A)$ After the preincubation in serum-free DME, ventricular cells were treated with actinomycin D (AMD) (5 $\mu \mathrm{g} /$ $\mathrm{ml}$ ), or simultaneously treated with actinomycin D and $10 \mu \mathrm{g} / \mathrm{ml}$ of cycloheximide $(A M D+C H X)$. The steady state levels of BNP mRNA and ANP mRNA were examined at the indicated times, and the disappearance rates of preexisting $\mathrm{mRNAs}$ were evaluated by Northern blotting analyses. $(B)$ Ventricular cardiocytes were treated with $10^{-8} \mathrm{M}$ of ET-1 for $36 \mathrm{~h}$. Hypertrophied myocytes were further treated with actinomycin D, and the mRNA disappearance rates were analyzed. ( $C$ ) Ventricular cardiocytes were treated with $10 \mu \mathrm{g} / \mathrm{ml}$ of cycloheximide $(\mathrm{CHX})$ for the indicated times, and the mRNA levels of BNP and ANP were examined.

In both states, the ANP mRNA level remained unchanged throughout the experiment period of $12 \mathrm{~h}$ (half-life $>12 \mathrm{~h}$ ).

Turnover rate of BNP mRNA was significantly decreased in the presence of cycloheximide (Fig. $7 A$ ), and the treatment with cycloheximide alone resulted in the increase in the steady state level of BNP mRNA; while it did not affect the ANP mRNA level (Fig. $7 C$ ). These findings suggest that BNP mRNA is rapidly degraded through a translation-dependent destabilization mechanism in cultured ventricular cardiocytes.

\section{Discussion}

In the present study, we examined the regulation of the BNP gene expression, in comparison with that of ANP, in cultured neonatal rat ventricular cardiocytes. During the course of cardiocyte hypertrophy, the rapid induction of the BNP gene expression occurred as fast as the "immediate-early" induction of the c-fos gene expression, and reached a maximal level within $1 \mathrm{~h}$. This rapid induction of the BNP gene expression was generated through transcriptional up-regulation, and did not require de novo synthesis of transacting regulatory factors. In contrast, the steady state level of ANP mRNA began to increase $3 \mathrm{~h}$ after the stimulation. Accumulation of MLC- 2 mRNA and increase in cell size were obviously observed at 12-24 h. These results indicate that the gene expression of BNP is distinctly regulated from that of ANP during the process of cardiocyte hypertrophy, and that the induction of the BNP gene expression is one of the earliest events preceding the establishment of cardiocyte hypertrophy.

Recent studies have demonstrated the differential expressions of several cardiac-specific genes during cardiocyte hypertrophy (27-34). Rapid and transient expressions of immediateearly genes including cellular protooncogenes initially occur. Augmented expression of the ANP gene and subtype switching or up-regulation of the contractile protein gene expression are generated later during the process of cardiocyte hypertrophy. The time course of the BNP gene expression during cardiocyte hypertrophy elucidated in the present study suggests that the BNP gene should be classified into a new category of the inducible cardiac-specific genes, which exhibits characteristics of both "immediate-early" induction and sustained activation of gene expression during myocardial cell hypertrophy.
As was the case with ET-1, phenylephrine or PMA evoked cardiocyte hypertrophy and induced rapid increase in the BNP mRNA level during the course of cell hypertrophy. These results were well consistent with the recent reports $(42,43)$. Since ET1 , phenylephrine, and PMA activate PKC, the rapid induction of the BNP gene expression is likely to be a common feature seen in cardiocyte hypertrophy evoked by PKC activators. Furthermore, our present study demonstrated that PKC inhibitors significantly suppressed the rapid BNP gene expression induced by ET-1. These results suggest that PKC activation is one of the proximal signaling pathways in the rapid induction of the BNP gene expression, which is consistent with previous reports to show that PKC activation is a common signaling event in the inducible expressions of several cardiac-specific genes during cardiocyte hypertrophy $(32,34)$. It is known that ET-1 activates several signaling pathways in cardiocytes, such as inositol phospholipid hydrolysis, diacylglycerol formation, and increase in intracellular calcium concentration $(31,33,34)$. Since the inhibitory effects of PKC inhibitors upon the ET-1-induced BNP gene expression were not complete even at high concentrations, it remains possible that intracellular events other than PKC activation may also lead to the rapid induction of the BNP gene expression. It will be of further necessity to determine whether activation of PKC is a crucial and restricted pathway to the induction of the BNP gene expression, and how the differential expressions of cardiac-specific genes occur during the process of cardiocyte hypertrophy.

The 5'-flanking promoter region of the ANP gene has been intensively studied (44-49), and the AP-1 (activator protein1) binding site is shown to be a critical cis-element in the induction of the ANP gene expression in cardiac hypertrophy (49). Very recently, the 5'-flanking sequence of the rat BNP gene was characterized, and the promoter analysis indicated that the interaction between GATA element and GATA-4 protein is involved in the cardiac-specific and inducible expression of the rat BNP gene $(50,51)$. The AP-1 site and GATA element exist in the promoter regions of BNP and ANP in various species including humans $(25,50,52,53$, Ogawa, Y., H. Itoh, O. Nakagawa, G. Shirakami, N. Tamura, K, Nagata, N. Yoshida, and K. Nakao manuscript submitted for publication), and may play pivotal roles in the gene expressions of BNP and ANP in the heart. However, the mechanism of the rapid transcriptional acti- 
vation of BNP in cardiocyte hypertrophy, which we demonstrated in the present study, has not been elucidated. Further studies are necessary to clarify the precise mechanism of the differential gene regulation of BNP and ANP in cardiac hypertrophy.

The present study revealed that the turnover rate of BNP mRNA in cultured ventricular cardiocytes is much faster than that of ANP mRNA. In addition, the translational blockade with cycloheximide decreased the BNP mRNA turnover rate and caused the accumulation of BNP mRNA. BNP mRNA contains an AU-rich sequence including several repeat units of AUUUA motif in the $3^{\prime}$-untranslated region $(4,54)$. This feature is conserved among species, sharply distinguishing BNP mRNA from ANP mRNA. This AUUUA motif is generally found in the mRNAs of transiently expressed genes for cytokines, growth factors, or cellular protooncoproteins, and is involved in the translation-dependent mRNA degrading mechanism (55-57). BNP mRNA is likely to be rapidly degraded through this selective decay pathway. These observations indicate that the gene expression of BNP is distinctly regulated from that of ANP at a posttranscriptional level as well as at a transcriptional level.

Furthermore, the half-life of BNP mRNA was longer in ET-1-induced hypertrophied cells, as compared with that in control, unhypertrophied cells. Prolongation of BNP mRNA half-life is also observed in phenylephrine-evoked cardiocyte hypertrophy (43), and it has been reported that various vasoactive hormones regulate mRNA stability of crucial molecules in vascular smooth muscle cells or skeletal muscle cells (58, 59). Although the present study showed that the rapid induction of the BNP gene expression by ET-1 is mainly transcriptional (Fig. 6), the sustained elevation of the BNP mRNA level in established cardiocyte hypertrophy may occur not only at transcriptional level but also at posttranscriptional level.

The secretion of BNP from ventricular cardiocytes was immediately stimulated by the treatment with ET-1; while the ANP secretion gradually increased in a time-dependent fashion. The secretory patterns of BNP and ANP were in parallel with the changes of the BNP mRNA and ANP mRNA levels, respectively. These results support the notions that BNP and ANP are secreted from ventricular cells promptly after synthesis via a constitutive pathway, although they are stored in the secretory granules in the atrium and are secreted via a regulated pathway against secretagogues $(60)$. Taken together with the fact that the main source of circulating BNP is the ventricle (14), the ventricular gene expression of BNP can be considered to directly and promptly lead to the alterations in the plasma BNP concentration.

We recently demonstrated that the plasma BNP concentration rapidly and tremendously increases, in comparison with that of ANP, in the clinical course of acute myocardial infarction $(21,22)$. The increase in the plasma BNP concentration was negatively correlated with the cardiac index, indicating that the changes of the plasma BNP concentration reflect the severity of ventricular dysfunction. Furthermore, we have also demonstrated that, in the rat model of experimental myocardial infarction, the ventricular BNP mRNA level and BNP-LI increase more rapidly than those of ANP not only in infarcted region but also in noninfarcted region (61). These findings suggest that hemodynamic overload directly induces the rapid ventricular expression of the BNP gene in the early course of acute myocardial infarction, and that the gene expressions of BNP and ANP are differentially regulated during the process of ventricular
Table I. Characteristics of BNP and ANP

\begin{tabular}{|c|c|c|}
\hline & BNP & ANP \\
\hline \multicolumn{3}{|c|}{ Gene expression } \\
\hline \multicolumn{3}{|c|}{ Total mRNA content ${ }^{(9,11,14-16)}$} \\
\hline Normal & Ventricle $>$ atrium & Ventricle $<$ atrium \\
\hline Hypertrophy & Ventricle $\gg$ atrium & Ventricle $\geq$ atrium \\
\hline Induction* & Rapid & Slow \\
\hline mRNA turnover* & Rapid & Slow \\
\hline \multicolumn{3}{|c|}{ Circulating hormone } \\
\hline \multicolumn{3}{|c|}{ Plasma concentration ${ }^{(14,18,19)}$} \\
\hline Basal in normal man & $0.9 \pm 0.07 \mathrm{fmol} / \mathrm{ml}$ & $\begin{array}{l}6.4 \pm 0.9 \mathrm{fmol} / \mathrm{ml} \\
100 \text {-fold }\end{array}$ \\
\hline Clearance $^{(14)}$ & Slow (long-acting) & Rapid (short-acting) \\
\hline
\end{tabular}

Parentheses refer to the studies which demonstrated the characteristics of BNP and ANP. Asterisks refer to the present study.

hypertrophy in vivo both in humans and in rats. The present study succeeded in reproducing this striking characteristics of the BNP gene expression using an in vitro culture model of cardiac hypertrophy, which allowed us to precisely examine the temporal profile and the regulatory mechanism of the BNP gene expression during cardiocyte hypertrophy.

Upon ventricular overload, the rapid induction of the BNP gene expression occurs in the ventricle, and BNP is promptly secreted into circulation. BNP elicits vasodilation, natriuresis, diuresis, and inhibition of renin-angiotensin-aldosterone system (24), and should serve to reduce both cardiac preload and afterload as an "emergency-rescue" hormone against ventricular overload. When the significant atrial overload simultaneously occurs, ANP stored in the atrium is also secreted. The amount of ANP stored in the atrium, however, may often be insufficient to meet the sudden deterioration of the hemodynamic conditions. BNP, rapidly produced in and secreted from the ventricle, should, therefore, work to reduce increased workload in such an adverse circumstance. Subsequently, the ANP gene expression in the heart gradually increases in response to cardiac overload, and BNP and ANP might cooperatively serve to compensate cardiovascular dysfunction in the chronic congestive heart failure.

Furthermore, the demonstrations of the natriuretic peptide receptors in rat and human hearts $(62,63)$ raise a possibility that BNP and ANP may possess some intracardiac actions during cardiac hypertrophy. We recently demonstrated the production of C-type natriuretic peptide and the expression of its specific receptor in vascular walls, and have proposed that natriuretic peptides should act as local regulators especially for vascular growth inhibition $(35,64,65)$. BNP and ANP, produced in response to ventricular overload, may also be relevant to cardiac remodeling including hypertrophy as autocrine and/ or paracrine factors.

Table I summarizes the characteristics of BNP and ANP which were elucidated in our present and previous studies. BNP and ANP have various distinct features in tissue specificity and inducibility of the gene expression, mRNA turnover, alteration in the plasma concentration, and clearance from systemic circulation. BNP possesses characteristics suitable for its possible role as an "emergency-rescue" cardiac hormone against ventricular overload. BNP and ANP have distinct and complementary roles in the maintenance of cardiovascular homeostasis as an exquisite dual cardiac natriuretic peptide system. 


\section{Acknowledgments}

The authors express our cordial gratitude to Prof. $\mathrm{H}$. Imura for profitable general instruction. We thank Dr. K. Iwaki and Dr. T. Tamaoki for valuable advice on cell culture and PKC inhibitors. We also acknowledge excellent secretarial and technical assistance with Ms. H. Kitoh, Ms. K. Sasamoto, Ms. A. Takagoshi, and Ms. M. Shida.

This work was supported in part by research grants from the Japanese Ministry of Education, Science and Culture, the Japanese Ministry of Health and Welfare "Disorders of Adrenal Hormone" Research Committee, Japan, 1992, Japan Tobacco Inc., Yamanouchi Foundation for Research on Metabolic Disorders, Uehara Memorial Foundation, Inamori Foundation, and by a research grant for cardiovascular diseases (2A-3) from the Japanese Ministry of Health and Welfare.

\section{References}

1. Flynn, T. G., M. L. de Bold, and A. J. de Bold. 1983. The amino acid sequence of an atrial peptide with potent diuretic and natriuretic properties. Biochem. Biophys. Res. Commun. 117:859-865.

2. Kangawa, K., and H. Matsuo. 1984. Purification and complete amino acid sequence of $\alpha$-human atrial natriuretic polypeptide ( $\alpha$-hANP). Biochem. Biophys. Res. Commun. 118:131-139.

3. Rosenzweig, A., and C. E. Seidman. 1991. Atrial natriuretic factor and related peptide hormones. Annu. Rev. Biochem. 60:229-255.

4. Nakao, K., Y. Ogawa, S. Suga, and H. Imura. 1992. Molecular biology and biochemistry of the natriuretic peptide system. I: Natriuretic peptides. $J$. Hypertension. 10:907-912.

5. Nakao, K., Y. Ogawa, S. Suga, and H. Imura. 1992. Molecular biology and biochemistry of the natriuretic peptide system. II: Natriuretic peptide receptors. J. Hypertension. 10:1111-1114.

6. Burnett, J. C., Jr., P. C. Kao, D. C. Hu, D. W. Heser, D. Heublein, J. P. Granger, T. J. Opgenorth, and G. S. Reeder. 1986. Atrial natriuretic peptide elevation in congestive heart failure in the human. Science (Wash. DC). 231:1145-1147.

7. Cody, R. J., S. A. Atlas, J. H. Laragh, S. H. Kubo, A. B. Covit, K. S. Ryman, A. Shaknovich, K. Pondolfino, M. Clark, M. J. F. Camargo, et al. 1986. Atrial natriuretic factor in normal subjects and heart failure patients. Plasma levels and renal, hormonal, and hemodynamic responses to peptide infusion. J. Clin. Invest. 78:1362-1374.

8. Sugawara, A., K. Nakao, N. Morii, T. Yamada, H. Itoh, S. Shiono, Y. Saito, M. Mukoyama, H. Arai, K. Nishimura, et al. 1988. Synthesis of atrial natriuretic polypeptide in human failing hearts. Evidence for altered processing of atrial natriuretic polypeptide precursor and augmented synthesis of $\beta$-human ANP. J. Clin. Invest. 81:1962-1970.

9. Arai, H., K. Nakao, Y. Saito, N. Morii, A. Sugawara, T. Yamada, H. Itoh, S. Shiono, M. Mukoyama, H. Ohkubo, et al. 1988. Augmented expression of atrial natriuretic polypeptide (ANP) gene in ventricles of spontaneously hypertensive rats (SHR) and SHR-stroke prone. Circ. Res. 62:926-930.

10. Yasue, H., K. Obata, K. Okumura, M. Kurose, H. Ogawa, K. Matsuyama, M. Jougasaki, Y. Saito, K. Nakao, and H. Imura. 1989. Increased secretion of atrial natriuretic polypeptide (ANP) from the left ventricle in patients with dilated cardiomyopathy. J. Clin. Invest. 83:46-51.

11. Saito, Y., K. Nakao, H. Arai, K. Nishimura, K. Okumura, K. Obata, G. Takemura, H. Fujiwara, A. Sugawara, T. Yamada, et al. 1989. Augmented expression of atrial natriuretic polypeptide gene in ventricle of human failing heart. $J$. Clin. Invest. 83:298-305.

12. Sudoh, T., K. Kangawa, N. Minamino, and H. Matsuo. 1988. A new natriuretic peptide in porcine brain. Nature (Lond.). 332:78-81.

13. Ogawa, Y., K. Nakao, M. Mukoyama, G. Shirakami, H. Itoh, K. Hosoda, Y. Saito, H. Arai, S. Suga, M. Jougasaki, et al. 1990. Rat brain natriuretic peptide. Tissue distribution and molecular form. Endocrinology. 126:2225-2227.

14. Mukoyama, M., K. Nakao, K. Hosoda, S. Suga, Y. Saito, Y. Ogawa, G. Shirakami, M. Jougasaki, K. Obata, H. Yasue, et al. 1991. Brain natriuretic peptide (BNP) as a novel cardiac hormone in humans. Evidence for an exquisite dual natriuretic peptide system, ANP and BNP. J. Clin. Invest. 87:1402-1412.

15. Hosoda, K., K. Nakao, M. Mukoyama, Y. Saito, M. Jougasaki, G. Shirakami, S. Suga, Y. Ogawa, H. Yasue, and H. Imura. 1991. Expression of brain natriuretic peptide gene in human heart. Production in the ventricle. Hypertension (Dallas). 17:1152-1155.

16. Ogawa, Y., K. Nakao, M. Mukoyama, K. Hosoda, G. Shirakami, H. Arai, Y. Saito, S. Suga, M. Jougasaki, and H. Imura. 1991. Natriuretic peptides as cardiac hormones in normotensive and spontaneously hypertensive rats. The ventricle is a major site of synthesis and secretion of brain natriuretic peptide. Circ. Res. 69:491-500.

17. Tamura, N., Y. Ogawa, H. Itoh, H. Arai, S. Suga, O. Nakagawa, Y.
Komatsu, I. Kishimoto, K. Takaya, T. Yoshimasa, et al. 1994. Molecular cloning of hamster brain and atrial natriuretic peptide cDNAs: cardiomyopathic hamsters are useful models for brain and atrial natriuretic peptides. J. Clin. Invest. 94:10591068.

18. Mukoyama, M., K. Nakao, Y. Saito, Y. Ogawa, K. Hosoda, S. Suga, G. Shirakami, M. Jougasaki, and H. Imura. 1990. Human brain natriuretic peptide, a novel cardiac hormone. Lancet. 335:801-802.

19. Mukoyama, M., K. Nakao, Y. Saito, Y. Ogawa, K. Hosoda, S. Suga, G. Shirakami, M. Jougasaki, and H. Imura. 1990. Increased human brain natriuretic peptide in congestive heart failure. $N$. Engl. J. Med. 323:757-758.

20. Yoshimura, M., H. Yasue, K. Okumura, H. Ogawa, M. Jougasaki, M Mukoyama, K. Nakao, and H. Imura. 1993. Different secretion patterns of atrial natriuretic peptide and brain natriuretic peptide in patients with congestive heart failure. Circulation. 87:464-469.

21. Mukoyama, M., K. Nakao, K. Obata, M. Jougasaki, M. Yoshimura, E. Morita, K. Hosoda, S. Suga, Y. Ogawa, H. Yasue, and H. Imura. 1991. Augmented secretion of brain natriuretic peptide in acute myocardial infarction. Biochem. Biophys. Res. Commun. 180:431-436.

22. Morita, E., H. Yasue, M. Yoshimura, H. Ogawa, M. Jougasaki, T. Matsumura, M. Mukoyama, and K. Nakao. 1993. Increased plasma levels of brain natriuretic peptide in patients with acute myocardial infarction. Circulation. 88:82-91.

23. Saito, Y., K. Nakao, K. Nishimura, A. Sugawara, K. Okumura, K. Obata, R. Sonoda, T. Ban, H. Yasue, and H. Imura. 1987. Clinical application of atrial natriuretic polypeptide in patients with congestive heart failure: beneficial effects on left ventricular function. Circulation. 76:115-124.

24. Yoshimura, M., H. Yasue, E. Morita, N. Sakaino, M. Jougasaki, M. Kurose, M. Mukoyama, Y. Saito, K. Nakao, and H. Imura. 1991. Hemodynamic, renal, and hormonal responses to brain natriuretic peptide infusion in patients with congestive heart failure. Circulation. 84:1581-1588.

25. Ogawa, Y., H. Itoh, N. Tamura, S. Suga, T. Yoshimasa, M. Uehira, S. Matsuda, S. Shiono, H. Nishimoto, and K. Nakao. 1994. Molecular cloning of the complementary DNA and gene that encode mouse brain natriuretic peptide and generation of transgenic mice that overexpress the brain natriuretic peptide gene. J. Clin. Invest. 93:1911-1921.

26. Braunwald, E. 1992. Heart Disease. W. B. Saunders Company, Philadelphia. 393 pp.

27. Waspe, L. E., C. P. Ordahl, and P. C. Simpson. 1990. The cardiac $\beta$ myosin heavy chain isogene is induced selectively in $\alpha_{1}$-adrenergic receptorstimulated hypertrophy of cultured rat heart myocytes. J. Clin. Invest. 85:12061214.

28. Iwaki, K., V. P. Sukhatme, H. E. Shubeita, and K. R. Chien. 1990. $\alpha$ and $\beta$-adrenergic stimulation induces distinct patterns of immediate early gene expression in neonatal rat myocardial cells. fos/jun expression is associated with sarcomere assembly; egr-1 induction is primarily an $\alpha_{1}$-mediated response. $J$. Biol. Chem. 265:13809-13817.

29. Knowlton, K. U., E. Baracchini, R. S. Ross, A. N. Harris, S. A. Henderson S. M. Evans, C. C. Glembotski, and K. R. Chien. 1991. Co-regulation of the atria natriuretic factor and cardiac myosin light chain-2 genes during $\alpha$-adrenergic stimulation of neonatal rat ventricular cells. Identification of cis sequences within an embryonic and a constitutive contractile protein gene which mediate inducible expression. J. Biol. Chem. 266:7759-7768.

30 Parker, T. G., K.-L. Chow, R. J. Schwartz, and M. D. Schneider, 1990. Differential regulation of skeletal $\alpha$-actin transcription in cardiac muscle by two fibroblast growth factors. Proc. Natl. Acad. Sci. USA. 87:7066-7070.

31. Shubeita, H. E., P. M. McDonough, A. N. Harris, K. U. Knowlton, C. C. Glembotski, J. H. Brown, and K. R. Chien, 1990. Endothelin induction of inositol phospholipid hydrolysis, sarcomere assembly, and cardiac gene expression in ventricular myocytes. A paracrine mechanism for myocardial cell hypertrophy. J. Biol. Chem. 265:20555-20562.

32. Komuro, I., Y. Katoh, T. Kaida, Y. Shibazaki, M. Kurabayashi, E. Hoh, F. Takaku, and Y. Yazaki. 1991. Mechanical loading stimulates cell hypertrophy and specific gene expression in cultured rat cardiac myocytes. Possible role of protein kinase C activation. J. Biol. Chem. 266:1265-1268.

33. Ito, H., Y. Hirata, M. Hiroe, M. Tsujino, S. Adachi, T. Takamoto, M. Nitta, K. Taniguchi, and F. Marumo. 1991. Endothelin-1 induces hypertrophy with enhanced expression of muscle-specific genes in cultured neonatal rat cardiomyocytes. Circ. Res. 69:209-215.

34. Shubeita, H. E., E. A. Martinson, M. Van Bilsen, K. R. Chien, and J. Heller Brown. 1992. Transcriptional activation of the cardiac myosin light chain 2 and atrial natriuretic factor genes by protein kinase $\mathrm{C}$ in neonatal rat ventricular myocytes. Proc. Natl. Acad. Sci. USA. 89:1305-1309.

35. Suga, S., K. Nakao, H. Itoh, Y. Komatsu, Y. Ogawa, N. Hama, and H. Imura. 1992. Endothelial production of C-type natriuretic peptide and its marked augmentation by transforming growth factor- $\beta$. Possible existence of "vascula natriuretic peptide system". J. Clin. Invest. 90:1145-1149.

36. Sambrook, J., E. F. Fritsch, and T. Maniatis. 1989. Molecular Cloning: A Laboratory Manual, 2nd edition. Cold Spring Harbor Laboratory Press, Cold Spring Harbor, NY. 10.13, 13.42-13.77, 14.1-14.35, B.15.

37. Kumar, C. C., L. Cribbs, P. Delaney, K. R. Chien, and M. A. Q. Siddiqui. 
1986. Heart myosin light chain 2 gene. Nucleotide sequence of full length cDNA and expression in normal and hypertensive rat. J. Biol. Chem. 261:2866-2872.

38. Nakagawa, O., I. Tanaka, T. Usui, M. Harada, Y. Sasaki, H. Itoh, T. Yoshimasa, T. Namba, S. Narumiya, and K. Nakao. 1994. Molecular cloning of human prostacyclin receptor cDNA and its gene expression in the cardiovascular system. Circulation. 90:1643-1647.

39. Kambayashi, Y., K. Nakao, H. Itoh, K. Hosoda, Y. Saito, T. Yamada, M. Mukoyama, H. Arai, G. Shirakami, S. Suga, et al. 1989. Isolation and sequence determination of rat cardiac natriuretic peptide. Biochem. Biophys. Res. Commun. 163:233-240.

40. Aburaya, M., E. Suzuki, N. Minamino, K. Kangawa, K. Tanaka, and H. Matsuo. 1991. Concentration and molecular forms of brain natriuretic peptide in rat plasma and spinal cord. Biochem. Biophys. Res. Commun. 177:40-47.

41. Tamaoki, T., and H. Nakano. 1990. Potent and specific inhibitors of protein kinase C of microbial origin. Bio-Technology (NY). 8:732-735.

42. LaPointe, M. C., and J. R. Sitkins. 1993. Phorbol ester stimulates the synthesis and secretion of brain natriuretic peptide from neonatal rat ventricular cardiocytes: a comparison with the regulation of atrial natriuretic factor. $\mathrm{Mol}$. Endocrinol. 7:1284-1296.

43. Hanford, D. S., D. J. Thuerauf, S. F. Murray, and C. C. Glembotski. 1994. Brain natriuretic peptide is induced by $\alpha_{1}$-adrenergic agonists as a primary response gene in cultured rat cardiac myocytes. J. Biol. Chem. 269:26227-26233.

44. Seidman, C. E., D. W. Wong, J. A. Jarcho, K. D. Bloch, and J. G. Seidman 1988. Cis-acting sequences that modulate atrial natriuretic factor gene expression. Proc. Natl. Acad. Sci. USA. 85:4104-4108.

45. LaPointe, M. C., J. Wu, B. Greenberg, and D. G. Gardner. 1988. Upstream sequences confer atrial-specific expression on the human atrial natriuretic facto gene. J. Biol. Chem. 263:9075-9078.

46. Wu, J., M. C. LaPointe, B. L. West, and D. G. Gardner. 1989. Tissuespecific determinants of human atrial natriuretic factor gene expression in cardiac tissue. J. Biol. Chem. 264:6472-6479.

47. Rosenzweig, A., T. D. Halazonetis, J. G. Seidman, and C. E. Seidman 1991. Proximal regulatory domains of rat atrial natriuretic factor gene. Circulation. $84: 1256-1265$

48. Wu, J., B. Kovacic-Milivojevic, M. C. LaPointe, K. Nakamura, and D. G Gardner. 1991. Cis-active determinants of cardiac-specific expression in the human atrial natriuretic peptide gene. Mol. Endocrinol. 5:1311-1322.

49. Kovacic-Milivojevic, B., and D. G. Gardner. 1992. Divergent regulation of the human atrial natriuretic peptide gene by c-jun and c-fos. Mol. Cell. Biol. 12:292-301.

50. Grepin, C., L. Dagnino, L. Robitaille, L. Haberstroh, T. Antakly, and M. Nemer. 1994. A hormone-encoding gene identifies a pathway for cardiac but not skeletal muscle gene transcription. Mol. Cel. Biol. 14:3115-3129.

51. Thuerauf, D. J., D. S. Hanford, and C. C. Glembotski. 1994. Regulation of rat brain natriuretic peptide transcription. A potential role for GATA-related transcription factors in myocardial cell gene expression. J. Biol. Chem. 269:17772-17775.

52. Greenberg, B. D., G. H. Bencen, J. J. Seilhamer, J. A. Lewicki, and J. C. Fiddes. 1984. Nucleotide sequence of the gene encoding human atrial natriuretic factor precursor. Nature (Lond.). 312:656-658.

53. Seilhamer, J. J., A. Arfsten, J. A. Miller, P. Lundquist, R. M. Scarborough, J. A. Lewicki, and J. G. Porter. 1989. Human and canine gene homologs of porcine brain natriuretic peptide. Biochem. Biophys. Res. Commun. 165:650-658.

54. Kojima, M., N. Minamino, K. Kangawa, and H. Matsuo. 1989. Cloning and sequence analysis of cDNA encoding a precursor for rat brain natriuretic peptide. Biochem. Biophys. Res. Commun. 159:1420-1426.

55. Shaw, G., and R. Kamen. 1986. A conserved AU sequence from the 3' untranslated region of GM-CSF mRNA mediates selective mRNA degradation. Cell. 46:659-667.

56. Wilson, T., and R. Treisman. 1988. Removal of poly (A) and consequent degradation of c-fos mRNA facilitated by 3' AU-rich sequences. Nature (Lond.). 336:396-399.

57. Brawerman, G. 1989. mRNA decay: finding the right targets. Cell. 57:9-

58. Li, J., M. A. Perrella, J. Tsai, S. Yet, C. Hsieh, M. Yoshizumi, C. Patterson, W. O. Endege, F. Zhou, and M. Lee. 1995. Induction of vascular endothelial growth factor gene expression by interleukin- $1 \beta$ in rat aortic smooth muscle cells. J. Biol. Chem. 270:308-312.

59. Thelen, M. H. M., A. Muller, M. J. Zuidwijk, G. C. Van Der Linden, W. S. Simonides, and C. Van Hardeveld. 1994. Differential regulation of the expression of fast-type sarcoplasmic-reticulum $\mathrm{Ca}^{2+}$-ATPase by thyroid hormone and insulin-like growth factor-1 in the L6 muscle cell line. Biochem. J. 303:467474.

60. Bloch, K. D., J. G. Seidman, J. D. Naftilan, J. T. Fallon, and C. E. Seidman. 1986. Neonatal atria and ventricles secrete atrial natriuretic factor via tissue-specific secretory pathways. Cell. 47:695-702.

61. Hama, N., H. Itoh, G. Shirakami, O. Nakagawa, S. Suga, Y. Ogawa, I.

Masuda, K. Nakanishi, T. Yoshimasa, Y. Hashimoto, et al. 1995. Rapid ventricular induction of brain natriuretic peptide gene expression in experimental acute myocardial infarction. Circulation. In press.

62. Hosoda, K., K. Nakao, S. Suga, H. Arai, Y. Saito, M. Mukoyama, G. Shirakami, M. Jougasaki, Y. Ogawa, and H. Imura. 1990. Gene expression of three types of receptors for natriuretic peptides in human tissues. J. Hypertension. 8:S32. (Abstr.)

63. Nunez, D. J. R., M. C. Dickson, and M. J. Brown. 1992. Natriuretic peptide receptor mRNAs in the rat and human heart. J. Clin. Invest. 90:19661971.

64. Itoh, H., R. E. Pratt, and V. J. Dzau 1990. Atrial natriuretic polypeptide inhibits hypertrophy of vascular smooth muscle cells. J. Clin. Invest. 86:16901697.

65. Komatsu, Y., K. Nakao, H. Itoh, S. Suga, Y. Ogawa, and H. Imura. 1992. Vascular natriuretic peptide. Lancet. 340:622. 